\title{
Paradoxes in the Phenotype, Frequency and Roles of Myeloid-Derived Suppressor Cells During HIV Infection
}

This article was published in the following Dove Press journal: HIVIAIDS - Research and Palliative Care

\section{Muluneh Ademe $\mathbb{C}$ \\ Department of Microbiology, Immunology and Parasitology, College of Health Sciences, Addis Ababa University, Addis Ababa, Ethiopia}

Correspondence: Muluneh Ademe Email muluneh.ademe@aau.edu.et

\begin{abstract}
Myeloid-derived suppressor cells (MDSCs) are heterogeneous groups of pathologically activated myeloid cells with potent immunosuppressive function. Due to their role in negatively regulating the immune system, MDSCs have been strongly correlated with disease progression during HIV. However, findings vary considerably between studies. The dominant phenotype of MDSC subsets during HIV is not well ascertained. Moreover, there is no clear understanding on the clinical significance of MDSCs during HIV infection. The existing evidences showed the double-sided roles of MDSCs in HIV. On the one hand, MDSCs are linked to deleterious effects during HIV infection as they inhibit proliferation of protective $\mathrm{T}$ cell response. On the other hand, the immunosuppressive abilities of MDSCs were shown to be beneficial in curbing the damaging effects of persistent immune activation associated with chronic HIV infection. Therefore, this review aimed to describe the differences in the existing literatures pertaining to the phenotype, frequency and roles of MDSCs during HIV infection.
\end{abstract}

Keywords: MDSCs, phenotype, HIV, ART, therapeutic targets, paradox

\section{Introduction}

The human immunodeficiency virus (HIV) pandemic is responsible for millions of cases and deaths each year with a huge economic impact mainly on resource-poor settings. ${ }^{1}$ HIV infection involves multiple components of the immune system leading to severe immune suppression of the host. Immune suppression drives HIV patients to become prone to different co-morbidities. ${ }^{2,3}$ In recent times, myeloid-derived suppressor cells (MDSCs) have gained more attention due to their immunosuppressive properties, and their expansion has been correlated with disease progression of chronic infections such as HIV. ${ }^{4}$ However, the currently available evidences revealed paradoxical results regarding the phenotype, frequency and roles of MDSCs during HIV infection.

The main goal of this review is, therefore, to describe the gaps in the existing literatures pertaining to the phenotype, proportion and role of MDSCs during HIV infection. For the purpose of preparing this review, systematic searches of articles were done from September - December 2019. Articles were identified using the search engines: Google scholar, Google search, Scopus and Pub-Med Central. The following keywords (phrases), including "HIV", "Pathogenesis", "ART", "Myeloid derived suppressor cells", "gMDSC", "mMDSC", "Phenotypes", "Mechanisms", and 
"Therapeutic approach" were used to find articles. Peerreviewed research articles, reviews and short communications identified during the search were screened by title and abstract. The search was restricted to the English language.

\section{Myeloid-Derived Suppressor Cells (MDSCs)}

The immature myeloid cells leave the bone marrow (BM) as myeloid precursor cells and migrate to peripheral tissues, such as spleen, where they differentiate into macrophages, dendritic cells and granulocytes or neutrophils. ${ }^{5}$ However, under certain pathological conditions, such as progressive infection, inflammation or a growing tumor burden, these immature myeloid cells follow a different differentiation pathway to produce MDSCs. ${ }^{6}$ The hallmark of MDSCs is their ability to suppress $\mathrm{T}$ cell and NK cell responses through different mechanisms, including the production of arginase1 (ARG1), indoleamine 2,3-dioxygenase (IDO), reactive oxygen species (ROS), inducible nitric oxide synthase (iNOS), TGF- $\beta$, IL-10, PD-L1 expression and the expansion of regulatory T cells (Treg). ${ }^{7,8}$

Usually, MDSCs do not expand and maintain a relatively low level in peripheral blood and tissues. ${ }^{9}$ For instance, in healthy mice, MDSCs constitute $20-30 \%$ of the total cells in BM, $2-4 \%$ of peripheral blood cells, $2-4 \%$ of spleen cells, $2-5 \%$ of liver cells, and $<1 \%$ of lymph node cells. ${ }^{9,10}$ However, during infection and cancer, MDSCs expand making up to $50 \%$ of the total cells in lymph nodes and bone marrow. ${ }^{10}$ Multiple factors may influence the expansion of MDSCs during disease conditions such as HIV. Notably, the immunological stress in pathological situations leads to emergency hematopoiesis to guarantee proper supply of both lymphoid and myeloid cells to increased demand. ${ }^{11}$ During this period, immature myeloid cells in the bone marrow are recruited to sites of inflammation to replace damaged or exhausted cells, and then become trapped in the local microenvironment where they acquire their immunosuppressive properties from various inflammatory signals. $5,12,13$

In humans, MDSCs are not a defined subset but a heterogeneous population without specific markers (Table 1). Currently, three subtypes of MDSCs are described, including Monocytic (m)-MDSCs which are defined as HLA$\mathrm{DR}^{-/ 1 \text { low }} \mathrm{CD} 33^{+} \mathrm{CD} 11 \mathrm{~b}^{+} \mathrm{CD} 14^{+}$, polymorphonuclear or granulocytic (g)-MDSCs which are defined as Lin HLA-DR ${ }^{-/ \text {low }}$ $\mathrm{CD}_{3} 3^{+} \mathrm{CD} 11 \mathrm{~b}^{+} \mathrm{CD} 15^{+}$and early-stage (e-) MDSCs with phenotypical makers as Lin $^{-}$(including CD3, CD14, CD15, CD19, CD56) HLA-DR ${ }^{-/ \mathrm{low}} \mathrm{CD} 33^{+} .14,15$
Table I Cell Surface Markers for Human MDSCs

\begin{tabular}{|l|l|l|}
\hline \multirow{2}{*}{ Phenotype } & \multicolumn{2}{|l|}{ Human MDSCs } \\
\cline { 2 - 3 } & mMDSC & gMDSC \\
\hline CDIIb & + & + \\
HLA-DR & Low/- & Low/- \\
CDI4 & + & - \\
CDI5 & - & + \\
CDI6 & High & Int. \\
Lin & - & - \\
CDI25 & + & + \\
CDI24 & + & + \\
CD33 & High & Int. \\
VEGFRI & \pm & + \\
CD83 & - & - \\
CD66b & - & High \\
\hline
\end{tabular}

\section{Phenotype and Frequency of MDSCs During HIV Infection}

Most studies come to an understanding that HIV infection promotes generation of MDSCs. ${ }^{14,15}$ However, the predominant phenotype of MDSCs during HIV infection is not well defined. Findings vary considerably between studies, partly due to methodological differences (Table 2). At various times, gMDSC and mMDSC subsets have been linked to the pathogenesis of HIV.

\section{mMDSCs During HIV Infection}

A large number of studies suggest that mMDSC expand during HIV infection and it correlates to HIV disease progression. A study by Gama et al on SIV infected macaques and HIV patients demonstrated that monocytes resembling mMDSC with surface expression of $\mathrm{CD} 14^{\text {high }} \mathrm{CD} 16^{\text {neg }} \mathrm{CCR} 2^{\text {low/neg }}$ expand with an effect on the proliferation of $\mathrm{CD} 8^{+} \mathrm{T}$ cells. ${ }^{16}$ Qin and colleagues also reported an increase in mMDSCs in the peripheral blood of HIV-1 seropositive individuals, and no considerable change was observed for the granulocytic subset $(\mathrm{CD} 11 \mathrm{~b}+\mathrm{CD} 33+\mathrm{CD} 14-\mathrm{CD} 15+)$ in HIV+ donors compared to healthy controls. ${ }^{17}$ In the study by Garg et al, viral gp120 but not gp41 induced mMDSC with surface markers of $\mathrm{CD} 11 \mathrm{~b}^{+} \mathrm{CD} 33^{+} \mathrm{CD} 14^{+} \mathrm{HLA}-\mathrm{DR}^{-/ 1 \mathrm{lo}}$ expanded during HIV infection. ${ }^{18}$ Garg et al also added that mMDSCs expansion positively correlated to increased IL-10 and $\mathrm{CD} 4+\mathrm{CD} 25+\mathrm{FoxP} 3+$ regulatory $\mathrm{T}$-cell levels which may collectively contribute to the severe immunosuppression observed in HIV patients. ${ }^{18}$ 
Table 2 Phenotypes of MDSCs and Their Mechanisms of Pathology During HIV Infection

\begin{tabular}{|c|c|c|c|c|}
\hline Study Subjects & MDSC Markers & MDSC Phenotype & $\begin{array}{l}\text { Role of MDSCs in HIV } \\
\text { Pathogenesis }\end{array}$ & References \\
\hline $\begin{array}{l}97(\mathrm{HIV+} \text { and } \\
\text { controls) }\end{array}$ & $\mathrm{CDIIb}^{+} \mathrm{CD} / 4^{-} \mathrm{CD}_{3} 3^{+} \mathrm{CD} / 5^{+}$ & gMDSC expanded & $\begin{array}{l}\text { Elevated viral load, low CD4 count } \\
\text { and increased Tregs }\end{array}$ & [23] \\
\hline $18 \mathrm{HIV+}$ & $\mathrm{CD} 14^{\text {high }} \mathrm{CD} 16^{\text {neg }} \mathrm{CCR} 2^{\text {low/neg }}$ & mMDSC expanded & Dampen expansion of CD8+ T cells & [16] \\
\hline $\begin{array}{l}\mathrm{II} 2 \text { (HIV+ and } \\
\text { controls) }\end{array}$ & $\begin{array}{l}\text { HLA-DR }{ }^{-1 l o w} \mathrm{CDIIIb}^{+} \mathrm{CD} 33^{+/} \\
\text {high } \mathrm{CD} / 4^{+} \mathrm{CD} 15^{-}\end{array}$ & mMDSC expanded & $\begin{array}{l}\text { Increased viral load, low CD4+ } \\
\text { T cell, elevated arginase I }\end{array}$ & {$[17]$} \\
\hline $37 \mathrm{HIV+}$ & $\mathrm{CDI}^{+} \mathrm{CD}_{3}{ }^{+/ \operatorname{dim}} \mathrm{CDIIb}^{+}$ & gMDSC expanded & $\begin{array}{l}\text { High levels of PD-LI, T cell } \\
\text { exhaustion }\end{array}$ & [24] \\
\hline $\begin{array}{l}10(\mathrm{HIV+} \text { and } \\
\text { controls) }\end{array}$ & $\mathrm{CD} / \mathrm{lb}^{+} \mathrm{CD} 33^{+} \mathrm{CD} / 4^{+} \mathrm{HLA}-\mathrm{DR}{ }^{-1 / \mathrm{o}}$ & mMDSC expanded & $\begin{array}{l}\text { Increased IL-10, Tregs and T cell } \\
\text { Suppression }\end{array}$ & {$[18]$} \\
\hline $105 \mathrm{HIV}+$ & HLA-DR ${ }^{\text {low }} \mathrm{CD} / \mathrm{Ib}^{+} \mathrm{CD} 33^{+} \mathrm{CD} / 5^{+}$ & gMDSC expanded & $\begin{array}{l}\text { Lower } \mathrm{CD} 3 \zeta \text { level, induce T-cell } \\
\text { anergy }\end{array}$ & [25] \\
\hline $\begin{array}{l}67 \text { (HIV/HCV and } \\
\text { controls) }\end{array}$ & 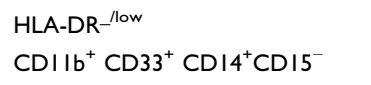 & mMDSC expanded & $\begin{array}{l}\text { Inflammation due to persistent } \\
\text { activated } T \text { cells }\end{array}$ & [19] \\
\hline I38 children & 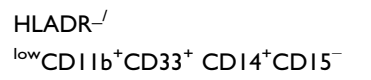 & mMDSC expanded & High IDO expression & [20]] \\
\hline $16 \mathrm{HIV+}$ & $\mathrm{CDI}^{\mathrm{lb}} \mathrm{b}^{+} \mathrm{CD} 33^{+} \mathrm{CD} / 4^{+} \mathrm{HLA} \mathrm{DR}^{-/ 1 \mathrm{o}}$ & mMDSC expanded & $\begin{array}{l}\text { Control production of IFN } \gamma \text {, } \\
\text { induction of IL-10 }\end{array}$ & {$[21]$} \\
\hline $\begin{array}{l}12 \text { macaques with } \\
\text { SHIV }\end{array}$ & $\begin{array}{l}\text { HLA-DR }{ }^{\text {low }} \mathrm{CD} / \mathrm{Ib}^{+} \mathrm{CD} 33^{+} \mathrm{CD} / 4^{+} \\
\text {or } \mathrm{CD} / 5^{+}\end{array}$ & $\begin{array}{l}\text { mMDSC expanded in the periphery but } \\
\text { decreased in BM }\end{array}$ & $\begin{array}{l}\text { Low MDSC in BM favors pathologic } \\
\text { immune activation }\end{array}$ & [22] \\
\hline 19 rhesus macaques & 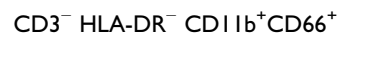 & gMDSC expanded & $\begin{array}{l}\text { Suppression of CD4+ and CD8+ } \\
\text { T cell proliferation }\end{array}$ & [26] \\
\hline $60 \mathrm{HIV}$ patients & $\begin{array}{l}\text { HLA-DR low } \\
\mathrm{CDIII}^{+} \mathrm{CD} 33^{+} \mathrm{CDI} / 4^{-} \mathrm{CDI} 5^{+}\end{array}$ & gMDSC expanded & $\begin{array}{l}\text { Low gMDSC (<6\%) correlated to } \\
\text { high viral load }\end{array}$ & [27] \\
\hline
\end{tabular}

In HIV-1/Hepatitis C Virus (HCV) co-infected patients, there was an expansion of mMDSCs which positively correlated with HIV disease markers, including low CD4+ T cell counts and high plasma viral load. ${ }^{19}$ Likewise, in children with HIV infection ${ }^{20}$ and in patients co-infected with HIV and Cytomegalovirus (CMV) ${ }^{21}$ mMDSCs were shown to be the predominant subsets. Recently, a 13-fold increase of the mMDSC (CD14+ MDSC) subset than the gMDSC (LinCD15+MDSC) subset was observed in the peripheral blood of SIV infected Indian rhesus macaques. ${ }^{22}$ Meanwhile, findings from the same study ${ }^{22}$ showed that the frequency of mMDSCs in the BM was paradoxically and unexpectedly decreased (dropping from $22 \%$ to $8 \%$ ) possibly due to mobilization of MDSCs from bone marrow to peripheral tissues, the slow self-replenishment of MDSCs in the bone marrow and viral infection induced depletion.

\section{gMDSCs During HIV Infection}

Contrary to what was said earlier, granulocytic subsets of MDSCs were shown to dominantly expand during HIV infection. In a study by Vollbrecht et al, subjects with progressive or chronic uncontrolled HIV infection had significantly higher levels of gMDSC (CD11b+CD14-CD33+CD15+), and percent gMDSC correlated positively with high viral load $(>50,000 / \mathrm{mL})$, low CD4 count $\left(<250 / \mathrm{mm}^{3}\right)$ and an increase in Tregs. ${ }^{23}$ Moreover, the proportion of low-density neutrophils (LDNs) with similar phenotype of gMDSCs $\left(\mathrm{CD} 15^{+} \mathrm{CD} 33^{+/ \mathrm{dim}} \mathrm{CD} 11 \mathrm{~b}^{+}\right)$were high in HIV-infected individuals'. ${ }^{24}$ Meanwhile, these LDNs positively correlate to increased expression of PD-L1 which led to suppression of T cell function via ROS and PD-L1/PD-1 pathways. ${ }^{24}$

Tumino and colleagues also reported an expansion of gMDSCs with subsequent decline in CD4+ T-cell count in HIV patients. ${ }^{25}$ In SIV infected rhesus macaques, gMDSCs were shown to be the dominant MDSCs comprising a median $90 \%$ of the total MDSC population over the course of SIV infection. ${ }^{26}$ A report from Agrati et al also showed that HIV disease progression correlates with an increase in gMDSC subsets. ${ }^{27}$ In the same study, ${ }^{27}$ despite an expansion of gMDSCs, HIV patients with low gMDSC frequency $(<6 \%)$ 
had a higher HIV DNA level than individuals with high gMDSC frequency $(>6 \%)$, suggesting that gMDSC might interfere with HIV reservoir establishment.

\section{Protective and Pathological Roles of MDSCs During HIV Infection}

\section{Deleterious Role of MDSCs During HIV Infection}

MDSCs will determine the clinical outcome of chronic HIV infections, and their effect has been shown to be either damaging or beneficial to the host. ${ }^{28}$ In most cases, MDSCs are believed to have deleterious effects, and they are linked to HIV disease progression. ${ }^{16,23}$ On the one hand, MDSCs directly hinder protective T-cell response by decreasing proliferation of $\mathrm{CD} 4+$ and $\mathrm{CD} 8+\mathrm{T}$ cells. ${ }^{7,23}$ On the other hand, MDSCs promote expansion of IL-10, $\mathrm{CD} 4+\mathrm{CD} 25+\mathrm{FoxP} 3+$ regulatory $\mathrm{T}$-cells and transiently induce PD-L1 expression leading to $\mathrm{T}$ cell exhaustion. ${ }^{7,24}$ In this regard, MDSC driven decline in protective $\mathrm{T}$ cell response and subsequent expansion of immune regulatory cells and molecules facilitate persistent HIV infections. ${ }^{24}$

Chronic immune activation, which mainly results from translocation of microbial products from damaged mucosa into the bloodstream, is another important driving force in HIV disease progression. ${ }^{29,30}$ A significant correlation of MDSCs proportion with pathological immune activation was observed in HIV patients with worsened severity of clinical conditions. ${ }^{19,22}$

\section{Beneficial Role of MDSCs During HIV Infection}

Under normal physiologic conditions, the body generates physiologically necessary immature myeloid cells which bear MDSC analogous phenotypes to sustain homeostasis. MDSCs appear to protect the host from devastating tissue damage during the initial stages of infection by attenuating an overwhelming inflammatory process. ${ }^{5,12}$

Contrary to previous reports, the immunosuppressive ability of MDSCs was shown to play a beneficial role in curbing the damaging effects of persistent immune activation and consequent systemic inflammation associated with chronic HIV infection. ${ }^{4}$ For instance, HIV patients co-infected with Cytomegalovirus (CMV) suffer from $\mathrm{CMV}$ induced inflammation and immune activation contributing to immune senescence and cardiovascular disease complications. ${ }^{31}$ In this case, HIV patients co-infected with CMV were shown to benefit from expansions of mMDSCs as it inhibits CMV induced inflammation. ${ }^{21}$

However, due to limited data, it is very difficult to reach into a conclusion that MDSC expansion during HIV infection favors either disease progression or helps in limiting host damage induced by excessive immune activation.

\section{The Effect of ART/HAART on MDSCs}

In HIV-infected individuals, viral suppression by ART or HAART was shown to decrease the MDSC population, which usually starts to drop within 6 weeks of therapy. ${ }^{19,23,26}$ In some cases, the frequencies of MDSC in HIV patients with HAART were comparable to healthy controls. ${ }^{20}$ The decrease in stimuli due to viral suppression by ART/HAART might be attributed to the drop in the level of MDSC. Usually, persistent stimulation is needed to maintain a steady-state expansion of MDSCs. For instance, in cancer model, cultures of tumor-derived MDSCs in the absence of tumor-derived stimuli showed a significant decrease in MDSCs, giving rise to mature functional myeloid cells. ${ }^{13,32}$

However, despite prolonged ART/HAART, MDSCs starts to expand again and remain stably higher. ${ }^{17,33}$ A higher level of MDSCs after 84 weeks post-HAART was reported. ${ }^{19}$ Agrati et al also reported that 48 weeks of successful ART failed to normalize the frequency of MDSCs. ${ }^{27}$

\section{MDSCs as Therapeutic Targets for HIV Infection}

The specific mechanism of suppression that MDSCs use to inhibit disease-specific immune responses will be helpful in designing immunotherapeutic strategies. The net benefit of limiting the expansion of MDSCs contributes to the restoration of host immune response which helps to combat infection. ${ }^{6}$ In cancer, targeting MDSCs for therapeutics purpose showed promising results. ${ }^{34}$ For instance, in hepatocellular carcinoma, targeting MDSCs have been shown to enhance antitumor efficacy of sorafenib or immune checkpoint inhibitors. $^{34}$

Data are scarce regarding the use of MDSC targeted therapy for the treatment of HIV. However, taking into account that cytotoxic T-cell responses appear important in killing reactivated cells that harbor the latent HIV provirus, dampening the effects of MDSC suppression could be vital in purging the latent HIV reservoir. ${ }^{35}$ MDSC depletion was reported to enhance $\mathrm{T}$ cell responses in SIV infected rhesus macaques. ${ }^{35}$ In HIV-infected persons, depletion of MDSC significantly increased the numbers of IFN $\gamma$ producing activated CD4 $+\mathrm{T}$ cells making MDSCs new therapeutic targets to control the chronic immune activation and endothelial cell inflammation observed in 
HIV-infected persons. ${ }^{21}$ Tumino and colleagues showed that in-vitro depletion of MDSC induced up-regulation of $\mathrm{CD} 3 \zeta$ in $\mathrm{T}$ cells, restoring the functionality of $\mathrm{T}$ cells. ${ }^{25}$

In general, considering the understanding that MDSCs expand in HIV-infected individuals with subsequent $\mathrm{T}$ cell dysfunction, ${ }^{17}$ targeting MDSC populations could be an alternative strategy of immunotherapy for HIV. However, with all the above mentioned paradoxical findings, it will be too early to reach a conclusion on this point.

\section{Conclusion}

During chronic viral infections such as HIV, poor clinical outcomes correlate both with systemic inflammation and poor proliferative ability of HIV-specific T cells. MDSCs that expand during disease states have been greatly linked to the systemic inflammation and poor $\mathrm{T}$ cell function characteristic of chronic viral infections. However, whether these MDSCs are beneficial or deleterious to host immunity against HIV still remain an open question. To date, the phenotype and abundance of MDSCs in HIV patients is not clearly defined. Unquestionably, further works are needed to verify the phenotype of MDSCs and determine their effects in HIV disease progression. This will be helpful in designing MDSC targeted therapy for the treatment of HIV in the future.

\section{Abbreviations}

ARG-1, Arginase 1; gMDSCs, granulocytic myeloidderived suppressor cells; IDO, Indoleamine 2,3-dioxygenase; iNOS, Inducible nitric oxide synthase; mMDSCs, monocytic myeloid-derived suppressor cells; PD-L1, programmed death-ligand 1; ROS, reactive oxygen species.

\section{Acknowledgments}

First and foremost, I would like to thank God for giving me the courage and strength. My sincere gratitude also goes to my family and friends for their support.

\section{Disclosure}

The author reports no conflicts of interest in this work.

\section{References}

1. Maartens G, Celum C, Lewin SR. HIV infection: epidemiology, pathogenesis, treatment, and prevention. Lancet. 2014;384(9939):258-271. doi:10.1016/S0140-6736(14)60164-1

2. Zicari S, Sessa L, Cotugno N, et al. Immune activation, inflammation, and non-AIDS co-morbidities in HIV-infected patients under long-term ART. Viruses. 2019;11(3):1-19. doi:10.3390/v11030200

3. Deeks SG, Autran B, Berkhout B, et al. Towards an HIV cure: a global scientific strategy. Nat Rev Immunol. 2012;12(8):607-614.
4. Macatangay BJ, Landay AL, Rinaldo CR. MDSC: a new player in HIV immunopathogenesis. AIDS. 2012;26(12):1567-1569. doi:10.1097/ QAD.0b013e328355e 682

5. Dai J, El Gazzar M, Li GY, Moorman JP, Yao ZQ. Myeloid-derived suppressor cells: paradoxical roles in infection and immunity. J Innate Immun. 2015;7(2):116-126. doi:10.1159/000368233

6. Ostrand-Rosenberg S, Sinha P. Myeloid-derived suppressor cells: linking inflammation and cancer. J Immunol. 2009;182(8):4499-4506. doi:10.4049/jimmunol.0802740

7. Wang L, Zhao J, Ren JP, et al. Expansion of myeloid-derived suppressor cells promotes differentiation of regulatory T cells in HIV-1+ individuals. Aids. 2016;30(10):1521-1531. doi:10.1097/QAD.0000000000001083

8. Parker KH, Beury DW, Ostrand-Rosenberg S. Myeloid-derived suppressor cells: critical cells driving immune suppression in the tumor microenvironment. Adv Cancer Res. 2015;128:95-139.

9. Ilkovitch D, Lopez DM. The liver is a site for tumor-induced myeloid-derived suppressor cell accumulation and immunosuppression. Cancer Res. 2009;69(13):5514 \pm 21 . doi:10.1158/0008-5472.CAN-084625

10. Kusmartsev S, Gabrilovich DI. Role of immature myeloid cells in mechanisms of immune evasion in cancer. Cancer Immunol Immunother. 2006;55(3):237-245. doi:10.1007/s00262-005-0048-Z

11. Ueha S, Shand FHW, Matsushima K. Myeloid cell population dynamics in healthy and tumor-bearing mice. Int Immunopharmacol. 2011;11 (7):783-788. doi:10.1016/j.intimp.2011.03.003

12. Cuenca AG, Delano MJ, Kelly-Scumpia KM, et al. A paradoxical role for myeloid-derived suppressor cells in sepsis and trauma. Mol Med. 2011;17(3-4):281-292. doi:10.2119/molmed.2010.00178

13. Bronte V. Myeloid-derived suppressor cells in inflammation: uncovering cell subsets with enhanced immunosuppressive functions. Eur J Immunol. 2009;39(10):2670-2672. doi:10.1002/eji.200939892

14. Bronte V, Brandau S, Chen SH, et al. Recommendations for myeloidderived suppressor cell nomenclature and characterization standards. Nat Commun. 2016;7(1):12150. doi:10.1038/ncomms 12150

15. Filipazzi P, Huber V, Rivoltini L. Phenotype, function and clinical implications of myeloid-derived suppressor cells in cancer patients. Cancer Immunol Immunother. 2012;61(2):255-263. doi:10.1007/ s00262-011-1161-9

16. Gama L, Shirk EN, Russell JN, Carvalho KI, Li M, Queen SE. Expansion of a subset of CD14highCD16negCCR2low/neg monocytes functionally similar to myeloid-derived suppressor cells during SIV and HIV infection. J Leukoc Biol. 2012;91(5):803-816. doi:10.1189/jlb.1111579

17. Qin A, Cai W, Pan T, et al. Expansion of monocytic myeloid-derived suppressor cells dampens $\mathrm{T}$ cell function in HIV-1-seropositive individuals. $J$ Virol. 2013;87(3):1477-1490. doi:10.1128/JVI.01759-12

18. Garg A, Spector SA. HIV type 1 gp120-induced expansion of myeloid derived suppressor cells is dependent on interleukin 6 and suppresses immunity. $J$ Infect Dis. 2014;209(3):441-451. doi:10.1093/infdis/jit469

19. Lei AH, Yang Q, Cai WP, Liu YF, Lan Y, Qin AP. Clinical significance of myeloid-derived suppressor cells in human immunodeficiency virus- $1 /$ hepatitis C Virus-coinfected patients. Scand J Immunol. 2016;83(6):438-444. doi:10.1111/sji.12429

20. Plessis ND, Jacobs R, Gutschmidt A, et al. Phenotypically resembling myeloid derived suppressor cells are increased in children with HIV and exposed/infected with Mycobacterium tuberculosis. Eur J Immunol. 2017;47(1):107-118. doi:10.1002/eji.201646658

21. Garg A, Trout R, Spector SA. Human immunodeficiency virus type-1 myeloid derived suppressor cells inhibit cytomegalovirus inflammation through interleukin-27 and B7-H4. Sci Rep. 2017;7(1):1-15. doi:10.1038/srep44485

22. Sui Y, Frey B, Wang Y, et al. Paradoxical myeloid-derived suppressor cell reduction in the bone marrow of SIV chronically infected macaques. PLoS Pathog. 2017;13(5):1-28. doi:10.1371/journal. ppat. 1006395 
23. Vollbrecht T, Stirner R, Tufman A, et al. Chronic progressive HIV-1 infection is associated with elevated levels of myeloid-derived suppressor cells. AIDS. 2012;26(12):F31-7. doi:10.1097/QAD.0b013e328354b43f

24. Bowers NL, Helton ES, Huijbregts RP, Goepfert PA, Heath SL, Hel Z. Immune suppression by neutrophils in HIV-1 infection: role of PD-L1/PD-1 pathway. PLoS Pathog. 2014;10(3):1-9. doi:10.1371/ journal.ppat.1003993

25. Tumino N, Turchi F, Meschi S, Lalle E, Bordoni V, Casetti R. In HIVpositive patients, myeloid-derived suppressor cells induce T-cell anergy by suppressing $\mathrm{CD} 3 \zeta$ expression through ELF-1 inhibition. AIDS. 2015;29(18):2397-2407. doi:10.1097/QAD.0000000000000871

26. Dross SE, Munson PV, Kim SE, et al. Kinetics of myeloid derived suppressor cell frequency and function during SIV infection, combination antiretroviral therapy and treatment interruption. J Immunol. 2017;198(2):757-766. doi:10.4049/jimmunol.1600759

27. Agrati C, Tumino N, Bordoni V, et al. Myeloid derived suppressor cells expansion persists after early ART and may affect CD4 T cell recovery. Front Immunol. 2019;10:1-10. doi:10.3389/fimmu.2019.01886

28. Brudecki L, Ferguson DA, McCall CE, El Gazzar M. Myeloidderived suppressor cells evolve during sepsis and can enhance or attenuate the systemic inflammatory response. Infect Immun. 2012;80 (6):2026-2034. doi:10.1128/IAI.00239-12

29. Mudd JC, Brenchley JM. Gut mucosal barrier dysfunction, microbial dysbiosis, and their role in HIV-1 disease progression. J Infect Dis. 2016;214(2):S58-66. doi:10.1093/infdis/jiw258
30. Brenchley JM, Schacker TW, Ruff LE, et al. CD4+ T cell depletion during all stages of HIV disease occurs predominantly in the gastrointestinal tract. $J$ Exp Med. 2004;200(6):749-759. doi:10.1084/ jem. 20040874

31. van de Berg PJ, Yong SL, Remmerswaal EB, van Lier RA, Ten Berge IJ. Cytomegalovirus-induced effector T cells cause endothelial cell damage. Clin Vaccine Immunol. 2012;19(5):772-779. doi:10.1128/CVI.00011-12

32. Narita Y, Wakita D, Ohkur T, Chamoto K, Nishimura T. Potential differentiation of tumor bearing mouse $\mathrm{CD} 11 \mathrm{~b}+\mathrm{Gr}-1+$ immature myeloid cells into both suppressor macrophages and immunostimulatory dendritic cells. Biomed Res. 2009;30(1):7-15. doi:10.2220/ biomedres.30.7

33. Grützner EM, Hoffmann T, Wolf E, et al. Treatment intensification in HIV-infected patients is associated with reduced frequencies of regulatory T cells. Front Immunol. 2018;9(811):1-13. doi:10.3389/ fimmu.2018.00811

34. Lu LC, Chang C, Hsu C. Targeting myeloid-derived suppressor cells in the treatment of hepatocellular carcinoma: current state and future perspectives. J Hepatocell Carcinoma. 2019;6:71-84. doi:10.2147/ JHC.S159693

35. Shan L, Deng K, Shroff NS, et al. Stimulation of HIV-1-specific cytolytic $\mathrm{T}$ lymphocytes facilitates elimination of latent viral reservoir after virus reactivation. Immunity. 2012;36(3):491-501. doi:10.1016/j.immuni.2012.01.014
HIV/AIDS - Research and Palliative Care

\section{Publish your work in this journal}

HIV/AIDS - Research and Palliative Care is an international, peerreviewed open-access journal focusing on advances in research in HIV, its clinical progression and management options including antiviral treatment, palliative care and public healthcare policies to

\section{Dovepress}

control viral spread. The manuscript management system is completely online and includes a very quick and fair peer-review system, which is all easy to use. Visit http://www.dovepress.com/testimonials.php to read real quotes from published authors. 